\title{
Distribution of trematodes in waterfowl of Pavlodar Oblast (Kazakhstan)
}

\author{
Akhmetov K.K.. ${ }^{1 *}$, Maralbaeva D.G. ${ }^{1}$, Matsyura A.V. ${ }^{2}$ \\ ${ }^{1}$ S. Toraigyrov Pavlodar State University, Pavlodar, Kazakhstan \\ ${ }^{2}$ Altai State University, Barnaul, Russia \\ *Corresponding author email: kanakam61@mail.ru \\ Received: 25.08.2020. Accepted: 02.10.2020
}

\begin{abstract}
The article presents the parasitological studies of Trematoda, collected by complete helminthological dissections of birds in the Pavlodar region of the Republic of Kazakhstan. In Pavlodar region, we have currently diagnosed among the Trematoda, the presence of 16 species belonging to four subgenera and seven families. We supposed that there is a local pest-spot of Prosthogonimidae and Echinistomatidae in the north-east of Kazakhstan, because we have found marites in young migratory birds. We noted that the pest-spot of Echinostomatidae and Echinistomatidae (in years with their registration) in the territory of Pavlodar region was broad enough, because the trematode marites of these families were registered from the birds, sampled at the geographically remote waterbodies. We revealed that the hotspots of Prosthogonimidae localization varied, which was most likely determined by the annual climatic conditions.
\end{abstract}

Keywords: trematodes, fauna, distribution, Pavlodar region

\section{Introduction}

Nowadays, the parasitology as part of zoological science is still relevant (Ryss et al., 2018). The transformation of ecological systems with global scale, such as climate change, and features associated with anthropogenic influence definitely contribute to this. In this regard, the study of parasitic organisms, in particular helminths, the development cycle of which includes several organisms and features of the environment, can be the key to understanding recent changes and assessing the state of communities and ecosystems.

Echinostomatidae and Prosthogonimidae are fairly common cosmopolitan taxa of bird trematodes. Relevance of studying their prevalence and peculiarities of their confinement both to individual regions and fluctuation of infection rates is important not only for parasitological science, but also for practical applied services to prevent helminths of economically important bird species. Echinostoma revolutum and Hypoderaeum conoideum were localized in the intestines of domestic ducks and geese, wild waterfowl and marsh birds, and were much rarer in chickens, turkeys and pigeons (Galat, Yatusevich, 2015). Moreover, they could lead to their exhaustion and death even at low infection rates of birds, especially young (Yakovleva et al., 2011; Krasnolobova, 1961; Karpenko, 1975).

The development cycle of echinostomatis and prorostonimides is characterized by the presence of one or more hosts. Intermediate hosts of trematode, in the discussed region (Pavlodar region, Kazakhstan) are freshwater molluscs from genera Radix, Lymnaea, and Planorbis. Additional hosts in the cycle of development of prostonimide are dragonflies, in echinostomatid the above-mentioned species of molluscs and frogs (in the region more often there is an acute frog), some species of fish and insects (Galat, Yatusevich, 2015). Definitive hosts of both families are domestic and wild birds. Since the life cycle of the discussed trematode is associated with a wide range of intermediate hosts, the data on species diversity and intensity of infection with echinostomatides and protochanimides are indicators of the participation of different aquatic organisms in the food diet of wading birds (Ryzhikov, 1967). Wide geographical spread of Prosthogonimidae family trematode in Pavlodar region may indicate the existence of a large hearth or a large number of individual hearths of trematosis, at least in the years of its registrations. Absence of Prosthogonimidae family trematodes in early helminthological collections (2014-2018), apparently, was connected with the mismatching time of dragonflies mass production and changes in the diet of bird chicks (Maralbaeva, Akhmetov, 2019). The main reason for the high contamination of trematodes of Echinostomatidae family in waterfowl (prevalence 40.9\%) is the abundance of intermediate hosts, which are freshwater molluscs inhabiting different freshwater reservoirs. The larvae of these helminths, overwintering in the body of intermediate hosts, provide annual infestation of the birds (Maralbaeva, Akhmetov, 2020).

Therefore, the purpose of our study was to establish the distribution of trematodes among waterfowl in the Pavlodar region.

\section{Materials and methods}

To establish the fauna of the bird trematodes in Pavlodar region we used the method of full helminthological autopsy by K.I. Skryabin (1928). In total we investigated 131 specimens of waterfowl belonging to 14 species from 4 orders: Podicipediformes - great-crested grebe Podiceps cristatus $(\mathrm{n}=5)$, little grebe $P$. ruficollis $(\mathrm{n}=2)$; Ciconiiformes - bittern Botaurus stellaris $(\mathrm{n}=1)$; Gruiformes - coot Fulica atra $(\mathrm{n}=20)$; Anseriformes - mallard Anas platyrhynchos $(\mathrm{n}=26)$, teal $A . \operatorname{crecca}(\mathrm{n}=1)$, garganey $A$. querquedula $(\mathrm{n}=16)$, gadwall $A$. strepera $(\mathrm{n}=16)$, pintail A. acuta $(\mathrm{n}=10)$, common shoveler A. clypeata $(\mathrm{n}=8)$, common pochard Aythya ferina $(\mathrm{n}=22)$, tufted duck $A$. fuligula $(\mathrm{n}=3)$ and ruddy shelduck Tadorna ferruginea $(\mathrm{n}=1)$.

The birds were captured by hunters in 2012-2019 in the lakes of the North-Eastern part of the Republic within the Pavlodar region, namely in Bayanaul, Pavlodar, Zhelezin, Akkuly, and Terenkol. Bird mining and parasitological collection, the results of which are 
discussed in this article, were carried out annually from August to mid-September. The species were determined by K.K. Akhmetov according to the guide compiled by A.O. Solomatin (Solomatin, Shaymardanov, 2005). Species diagnostics of marigold trematode were done by K.K. Akhmetov according to K.M. Ryzhikov (1967).

The present study discusses the diversity of trematodes in birds from this year brood, which was established by the presence of bursal sac (Romer, Parsons, 1992). Therefore, we assumed that all birds caught are the local and typical in this region. In our work, special attention was paid to the taxa of trematode, which are of practical importance, because they are often found in wild and domestic birds and cause fairly common helminth infections. Such taxa in the Pavlodar region include representatives of echinostomatids and protogonimides.

Statistical processing of helminthological material, for some cosmopolitan types of trematodes, was carried out in accordance with the recommendations of G.F. Lakin (1990). To identify the host infestation, three main parameters of the number of parasites were calculated: prevalence, infection intensity, and abundance (Anikinova et al., 2007).

\section{Results and discussion}

Below is the systematics of identified trematodes:

Suborder Cyclocoelata (La Rue, 1957)

Family Cyclocoelidae (Stossith, 1902)

Cyclocoelium mutabile (Zeder, 1800)

Typhlocoelium cucumerinum (Rud., 1809)

Order Fasciolata (Skrjabin et Schulz, 1937)

Family Echinostomatidae (Dietz, 1909)

Echinostoma revolutum (Frochlich, 1802)

Hypoderaeum conoideum (Bloch, 1782)

Echinopariphium aconiatum (Dietz, 1909)

Family Notocotylidae (Luhe, 1909)

Notocotylus attenuates (Rud., 1809)

Notocotylus gibus (Rud. 1809)

Family Prosthogonimidae (Nicoll, 1924)

Shisthogonimus rarus (Braun, 1901)

Prosthogonimus cuneatus (Rud., 1809)

Prosthogonimus ovatus (Rud., 1803)

We did not register the representatives of this family in helminthological collections for 2014-2018d, and we only once noted them in 2019.

Family Psilostomatidae (Odhner, 1913)

Sphaeridiotrema globulus (Rudolphi, 1819)

Suborder Strieata (La Rue, 1926)

Family Strigeidae (Railliet, 1919)

Cotylurus cornutus (Rud, 1808)

Ichtiocotilurus platycephalus (Creplin, 1825)

Codonocephalus urnigerus (Rud., 1819)

Family Diplostomidae (Poirier, 1886)

Diplostomum huronense (La Rue, 1927)

Suborder Schistosomata (Sktjabin et Schulz, 1937)

Family Schisthosomatidae (Loos, 1899)

Dendrithobilharzia purverulenta (Skrjabin et Schuz, 1920)

Family Echinostomatidae is represented by Hypoderaeum conoideum (Bloch, 1782), Echinostoma revolutum (Fröelich, 1802) and Echinoparyphium aconiatum (Dietz, 1909), family Prosthogonimidae is represented by Prosthogonimus cuneatus and Schisthogonimus rarus.

Among 131 birds we studied, 83 individuals were invaded by trematodes from Prosthogonimidae (Luhe, 1909), which amounted to $67.2 \%$. Percentage of prostogonimosis infection in various bird families was as follows: Gruiformes - 60\% (coot), and Anseriformes $74.5 \%$ (mallard, teal, garganey, gadwall, pintail, common shoveler, common pochard, tufted duck, and ruddy shelduck). Prevalence ranged from 7.7 to $100 \%$. According to our data, the index of abundance of Prosthogonimidae in Anseriformes species was much higher than in cranes. The maximum abundance index was found in teal (1), while the minimum abundance index was registered in mallard (0.08). Intensity of invasion in Gruiformes varied from 1 to 1.17, in Anseriformes - from 0.85 to 1.5 . We, however, did not reveal some prostogonimids in Ciconiiformes (bittern) and Podicepidiformes (grebes).

Podicipediformes - great-crested grebe Podiceps cristatus $(\mathrm{n}=5)$, little grebe $P$. ruficollis $(\mathrm{n}=2)$; Ciconiformes - bittern Botaurus stellaris $(\mathrm{n}=1)$; Gruiformes - coot Fulica atra $(\mathrm{n}=20)$; Anseriformes - mallard Anas platyrhynchos $(\mathrm{n}=26)$, teal $A$. crecca $(\mathrm{n}=$ $1)$, garganey $A$. querquedula $(\mathrm{n}=16)$, gadwall $A$. strepera $(\mathrm{n}=16)$, pintail A. acuta $(\mathrm{n}=10)$, common shoveler $A$. clypeata $(\mathrm{n}=$ $8)$, common pochard Aythya ferina $(\mathrm{n}=22)$, tufted duck $A$. fuligula $(\mathrm{n}=3)$ and ruddy shelduck Tadorna ferruginea $(\mathrm{n}=1)$.

From 96 registered marites, $60.4 \%$ were identified as $S$. rarus and $38.5 \%$ as $P$. cuneatus. Trematode infestations of Prosthogonimidae species were found in garganey, coot. gadwall, pintail, mallard, pine, tufted duck, and ruddy shelduck. The combination of simultaneous infection by $P$. cuneatus and $S$. rarus was not registered. $S$. rarus was found in 52 this year brood birds from 11 , whereas $P$. cuneatus was registered in 36 this year brood birds of 10 species. 
The analysis of infection indexes by Echinostomatidae showed that 68 (51.9\%) of 131 studied birds were invaded. Among them $66 \%$ were Anseriformes: teal, gadwall, common pochard, tufted duck, mallard, pintail, and common shoveler. The intensity of invasion in these birds ranged from 6 to 73\%. Maximum abundance index was found in pintail (1.3), and minimum abundance index was found in garganey (0.06). The intensity in Anseriformes invasion ranged from 1.74 to 2.33 . No echinostomatids were found in Gruiformes, Ciconiiformes, and Podicipidiformes species.

$H$. conoideum was found in 51 this year brood birds of seven species, E. revolutum was registered in 17 birds of five species. E. aconiatum was found in 10 this year brood birds from seven species. Thus, $H$. conoideum was the most frequent echinostomatids species. The infection rate of Anseriformes with $\mathrm{H}$. conoideum marites was higher compare to other echinostomatid species.

We believe that there is local poset-spot of Prosthogonimidae and Echinistomatidae trematodes in the North-East of Kazakhstan, because we found the marites in the young birds during the summer. We noted that the pest-spot of Echinostomatidae and Echinistomatidae (during the years of registration this trematodes) was broad enough in the territory of Pavlodar region of Kazakhstan, because the trematode marites of these families were registered in birds, sampled at the geographically remote waterbodies. Hotspots of Prosthogonimidae trematodes localization varied, which probably determined by intra-annual climatic conditions. We will continue to clarify the fauna of regional trematodes, their biological and ecological characteristics.

\section{References}

Anikinova, V.S., Bugmyrin, S.V., Ieshko, E.P. (2007). Methods of collecting and studying helminths of small mammals. Institute of Biology, KarNC RAS. Petrozavodsk (in Russian).

Galat, V.F., Yatusevich, A.I. (2015). Guidelines for Veterinary Parasitology. Minsk. Data Center of the Ministry of Finance (in Russian).

Karpenko, S.B. (1975). The helminthfauna of passerine birds - inhabitants of lake hollows in the North-Kulunda forest-steppe. Parasites in natural complexes of North Kulunda. Novosibirsk. Nauka (in Russian).

Krasnolobova, T.A. (1961). Life cycle of the pathogen for the disease of hens Prosthogonimus cuneatus, Rud. 1809 (Trematoda). Helminthologia, 3(1-4), 183-192 (in Russian).

Lakin, G.F. (1990). Biometrics. Moscow. Vysshaya shkola (in Russian).

Maralbaeva, D.G., Akhmetov, K.K. (2019). Features of Prosthogonimidae family trematode distribution (Nicol, 1924) in birds in North-East Kazakhstan. Russian Parasitological Journal, 13(3), 63-70. (in Russian)

Maralbaeva, D.G., Akhmetov, K.K. (2020). Species of bird trematodes of the family Echinostomatidae (Dietz, 1909) common in northeast Kazakhstan from the point of view of the current state of the fauna. EurAsian Journal of Biosciences, 14, 1419-1425.

Romer, A., Parsons, T. (1992). Anatomy of vertebrates. Moscow. Mir (in Russian).

Ryss, A.Yu, Galaktionov, K.V., Pugachev, O.N., Medvedev, S.G., Leonovich, S.S. (2018). A brief review of the main directions of parasitology development in Russia. Parasitology, 52 (6), 500-510 (in Russian).

Ryzhikov, K.M. (1967). Definition of helminths of domestic waterfowl. Moscow. Science (in Russian).

Solomatin, A.O., Shaymardanov, J.K. (2005). Birds of the Pavlodar Priirtyshye (field guide). Pavlodar. PSPI Publisher (in Russian).

Yakovleva, G.A., Lebedeva, D.I., Ieshko, E.P. (2011). Echinostomatids of birds of Karelia. Scientific Notes of Petrozavodsk State University, 8, 24-28 (in Russian).

\section{Citation:}

Akhmetov, K.K., Maralbaeva,D.G., Matsyura, A.V. (2020). Distribution of trematodes in waterfowl of Pavlodar Oblast (Kazakhstan). Ukrainian Journal of Ecology, 10(4), 279-281.

(cc) Br 